\title{
Factors Affecting Students' Decision to Select Private Universities in Vietnam
}

\author{
Hung Quang LE*
}

Received: January 10, 2020 Revised: March 1, 2020 Accepted: March 6, 2020.

\begin{abstract}
The study seeks to identify factors affecting the choice of a university by first-year Business Administration students in Vietnam. Probability sampling is using Stratified sampling of 500 students from five private universities in Ho Chi Minh City surveyed by convenience sampling. This paper employs mixed research methods - measuring Cronbach's Alpha, EFA, Regression and using PATH model - to test the hypotheses of the research model. The results of the study identify five factors: Prestige, Geographical location, Facilities, Attractiveness of the field and Media. All these factors have a positive influence on the standing of the university brand. It means that the higher the Prestige, Geographical location, Facilities, Attractiveness of the field and Media, the higher the university brand. The results indicate that Geographical location is the most influential factor to enhance the private university's brand. Bringing Geographical location is, thus, advisable to enhance a university standing. The brand plays a determining role in students' trust when selecting a university. Media is still the top concern of new students when they choose to study at a university. Media still remains an important consideration for new students when choosing a university. So, this factor should be utilized by universities to enhance their attractiveness.
\end{abstract}

Keywords: Higher Education, Private Universities, University Brand, University Selection, Vietnam

JEL Classification Code: I23, I25, M31

\section{Introduction}

Nowadays Vietnam not only offers many types of higher educational institutions such as public, private universities or training universities under foreign affiliate programs, but also many opportunities for high school students to go to university. Today's situation is that some private universities cannot enroll students. Therefore, public and private universities are facing fierce competition in enrollment. Universities compete on geographical location, the buildup of new campuses and investment in modern

${ }^{*}$ First Author and Corresponding Author. Vice Dean, Faculty of Business Administration, Ho Chi Minh City University of Technology (HUTECH), Vietnam [Postal Address: 475A Dien Bien Phu Street, Ward 25, Binh Thanh District, Ho Chi Minh City, 70000, Vietnam] Tel: +84 916798955, Email: Iq.hung@hutech.edu.vn

(c) Copyright: The Author(s)

This is an Open Access article distributed under the terms of the Creative Commons Attribution Non-Commercial License (http://Creativecommons.org/licenses/by-nc/4.0/) which permits unrestricted noncommercial use, distribution, and reproduction in any medium, provided the original work is properly cited. educational equipment. Currently, Vietnamese universities go at great length in their use a variety of media to promote their image, their brand value, to attract students, given that University brand is the top priority for students and their family in choosing the establishment. Therefore, the selected research topic "Brand factors affecting the selection of a university by first-year Business Administration students: A case study of private universities in Ho Chi Minh City" will contribute to exploring the factors and suggest implications on enhancing private University brand in Ho Chi Minh City in the context of fierce competition to attract students.

The objectives of this research are to identify the University brand factors affecting the selection of university by first-year Business Administration students and to develop the research model related to the topic. In the model, some new aspects will be explored and discussed, such as (1) adding a Geographical location factor to enhance the private University brand, (2) assessing whether the higher the students' perception of the 
University brand, the higher the selection of a university by first-year Business Administration students, and (3) using PATH model to test the research hypotheses through the intermediate variable "University brand".

\section{Literature Review}

\subsection{Brand}

There are different views on brand. However, two main perspectives exist in the literature. Firstly, a brand is a name, symbol, sign, design or combination of these elements to identify a product or service of a manufacturer and distinguish it from other competitors' brands (Bennett, 1995; Nguyen \& Nguyen, 2011). Here, the basic function of a brand is to distinguish the product from others. The second view contends that the previous perspective of brand failed to explain its role in the context of the increasingly integrated and intensely competitive world economy.

Murphy (1987) generalizes the constituents of a brand to include "... product, packaging, trademark, propaganda, advertising and the whole process of product displays," and concludes that a brand is "the sum of all things in terms of tangible matters, aesthetics, senses and emotions." According to Kotler and Bliemel (1999), brand is a set of attributes providing values target customers require. Davis (2002) then suggests that brand is a "promise" of sellers to buyers about features and benefits of the product or services. Thus, the product is a part of the brand. Kotler and Bliemel (1999) claim that a brand is a successful medium for conveying the advantages and value that a service can provide because a brand is a guarantee of quality, source and capacity, and thus it increases the awareness and reduces the risk and complexity associated with purchasing decisions. In this present study, we advocate the second view. In business, a brand is not only a product, but also distinguishes it from other products and provides psychological needs to customers. Today's enterprises view brand as the most valuable asset that they hold.

\subsection{University Brand}

In the context of higher education being more commercial, the concept of University brand has been raising concerns from education researchers. Universities in the world have been adopting more and more integrated marketing techniques to design their brand communications. Harvey (1996) states that branding in higher education helps students and their parents specifically identify offered services offered they want to use. McNally and Speak (2002) define a university brand as the feeling or emotion of a student describing experiences of purchasing products or services of an academic institution. Bulotaite (2003) emphasizes that a university is a complex organization that only a brand is able to simplify this complexity and enhance its attractiveness to students and student loyalty. Schackner (2004), from Point Park University in Pittsburgh, announced a \$1-million branding campaign through billboards, newspaper ads, and other media. Hacker (2005), from University of Houston, launched a \$5-million campaign implemented over five years in an effort to build image and proactive access.

Balmer (2001) argues that many university managers have acknowledged the strategic importance of holding a strong brand in the educational sector. Hemsley-Brown and Goonawardana (2007) make the point that there is a dearth of experimental research on branding, identification and image related to the higher education sector. As Chapleo (2010) states, when mentioning the brand name of a university, it is obvious that "associations, emotions, images" of the university are immediately evoked. The mission of university branding is to build, manage and develop these impressions. Chapleo (2011) then find that branding in the higher education sector has been a controversial topic with little research and attention from researchers, though there are some studies on marketing in higher education. It should be noted that the Geographical location of a university is not mentioned in the above studies as a factor enhancing the brand value of the university (Le, 2019).

Sultan and Ho (2014) present an integrated model demonstrating not only the factors influencing service quality of a university, but also the results of delivering the service quality. The result of this study shows that past experiences are preconditions for perceived service quality (academy, administration, facility). The result of perceived service quality is Students' satisfaction, Confidence, Brand efficiency, and Behavioral intention of students. This model explained how the service quality is formed and how the perceived service quality affects university brand. It is essential for universities to consider this research model to gain sustainability in global competition, enhance brand efficiency as well as attract and retain students.

In Vietnam, Nguyen and Nguyen (2014) present a model of university branding consisting of Advertising, Activities of admissions consultancy, and Promotions during learning process and Word-Of-Mouth (WOM) activities. These four factors alter students' perceptions of a university image and reputation. This leads to a positive impact on students' loyalty to their university. In this study, the authors present basic theories of brand and branding in the business and education sectors. From this perspective, the arguments and research model on branding for Vietnamese education are demonstrated based on students' perception. However, this 
study develops research model, but has not yet verified the model. Therefore, it is necessary for the following modeling studies to be tested. Nguyen (2015) conducted a study on "Brand value of a university based on employees: Research in Vietnam". In this study, the author simultaneously took into account three groups of factors affecting brand value based on employees: (1) Marketing, (2) Human Resource Management and (3) Tasking Environment. The research results show that there are two factors directly affecting the components of brand value based on employees: (1) Internal branding, and (2) Organizational culture. In particular, Organizational culture is the most influential factor on brand value based on employees. Most research on university brand name in Vietnam has not synthetically studied subjects directly building brand value of the university are Lecturers, Staff and Students (Le, 2019).

\subsection{Students' Selection of University}

Howard and Sheth (1969) bring up five factors that influence customer buying decisions: (1) Quality, (2) Price, (3) Recognition, (4) Services and (5) Society. However, according to this model, these five factors do not directly affect the buying decision, but indirectly through a black box. This black box includes intermediate steps depending on the type of product or service. Chapman (1981) argues that universities' fixed factors such as Tuition, Geographical location, Expenses support policy and Environment of dormitory alter students' choice of university. In addition, following Chapman's findings (1981), Cabera and La Nasa (2000) studied the model of a 3-stage university selection by students. They emphasized that the expectations of task in the student's future is also an important group of factors that influence a student's university choice. Burn (2006) applied the findings from Chapman (1981) and Cabera and La Nasa (2000) to a specific university in the United States, once again confirming the above results: the relationship between groups of factors influence the student's choice of university.

Le, Nguyen, Tran, Diep, Ngo, Tran, and Nguyen (2014) synthesized groups of factors influencing students' selection of University, reviewed above. Subsequently, the authors developed a research model on additional aspiration choices of students from Ho Chi Minh City University of Technology (HUTECH) Faculty of Business Administration that includes the following factors: Benchmark, Prestige, Communication, Geographical Location, Facilities, Lecturers, Tuition and Assistance. The analysis found that Benchmark was rejected from the officially theoretical research model. The reason was that there was no difference in the Benchmarks of most private universities, so students were not interested in this factor. Research results also indicated that Lecturers and Geographical location significantly affect students' university choice. For Le (2017), the purpose of research is to identify the objective and subjective factors affecting the Brand value of HUTECH as mediated by students' perceptions. Using PATH model to test the hypotheses of the research model and the results indicate that a new factor, namely, Geographical location is the most influential factor to enhance the Brand value of HUTECH. Brand still plays a determinant role in students' trust when selecting a university.

In summary, based on the results of domestic and foreign studies, students' selection of a university is commonly influenced by factors such as Facilities, Academic quality, Lecturers, Career opportunities after graduation, University services, etc. Most of the current research in Vietnam has neither mentioned the first-year Business Administration students' consideration of Geographical location in selecting a university, nor demonstrated that the more satisfied students are with University brand, the more likely they select the university.

\subsection{Hypothesis}

In this study, the research model is based on previous research frameworks (Howard \& Sheth, 1969; Chapman, 1981; Sultan \& Ho, 2014) and two research models related to Vietnam (Le et al. 2014; Le, 2017). The research model is based on the PATH model in which the higher the students' perception of the university brand is, the higher the new students' decision to choose a private university. The PATH model is a multiple linear regression model with independent variables that are qualitative or quantitative variables; intermediate and independent variables are quantitative variables. Regression analysis with the PATH model is used to analyze the effect of the independent variable on the dependent variable through the intermediate variable. The PATH model is to test the hypotheses through the intermediate variable University brand.

Hypothesis 1: Geographical location has a positive effect on University brand.

The Geographical location of an enterprise is the place where the enterprise places its offices or factories. The tangible assets of the enterprise yield higher value in case its location is placed not only near the central areas of city, province, or district, but also in the area where transportation has been developed.

Hypothesis 2: Facilities has a positive effect on University brand. 
University facilities are systems constituted of various physical and technical elements such as campus, dormitory, libraries, educational facilities, and other facilities, etc., used for university education and training.

Hypothesis 3: Media has a positive effect on University brand.

The education is a type of service. Therefore, the university must build a separate media department to easily devise compelling image marketing strategies and promote its image to the public. Branding is the top task of universities in Vietnam today to attract good students,. There is a variety of media available to universities to raise their brand in a competitive education market.

Hypothesis 4: Prestige has a positive effect on University brand.

In the field of higher education, prestige is an important factor. There are many ways for the university to build prestige when conveying its image to the public. It is best for students, parents, alumni and the public to speak well of the university through academic activities, extracurricular activities, faculty and staff. The image and reputation of the university have a great influence on the student's choice of establishments.

Hypothesis 5: Attractiveness of the field has a positive effect on University brand.

Business administration is an attractive field many students want to study because graduates easily find job in enterprise. in departments such as Marketing, Business, Planning, and Operating in domestic and foreign companies. During the course of their study, students not only have many opportunities to experience what business is, but also can receive financial or career support from the university.

Hypothesis 6: University brand has a positive effect on First-year Business Administration students in selecting a university.

There exists a positive relationship between the University brand and First-year Business Administration students' university selection. The higher the students' perception of a university's brand, the higher their decision to select that university. In business, brand is not only a product, but also a factor distinguishing it from other products, and it provides psychological needs to customers. Today's enterprises view brand as the most valuable asset they possess. Higher education is a type of service.
Therefore, the university must build a prestigious brand to attract more students.

\section{Research Methodology}

\subsection{Operationalization}

Qualitative and quantitative methods are used in the process of constructing and testing models and hypotheses dealing with University brand factors affecting student's university selection.

\subsection{Qualitative Research}

Qualitative research method was conducted through the focus group discussion. Draft scales are used in the university discussion with 15 leaders, staff and lecturers and 15 undergraduate students of faculties of Business administration. Preliminary group discussions were crucial to test the interview framework in order to adjust the scale. Based on experts' documents and survey studies on Firstyear Business Administration students' university selection model, the basic effect factors were finalized. This study adjusts and adds observation variables used to measure concepts in the research model. The result of the qualitative research led to a correction of the scales as well as the elaboration of the official survey sheet used for the quantitative research. The questionnaire was designed based on 5-level Likert scale to assess University brand factors affecting students' decision. The official questionnaire consisted of 40 observation variables corresponding to seven scales of the research model: (1) Geographical location, (2) Facilities, (3) Prestige, (4) Attractiveness of the field, (5) Media, (6) University brand and (7) First-year Business Administration students' University selection.

The concept of Geographical location is denoted by GL and measured by six observed variables; the concept of Facilities is denoted by FAC and measured by seven observed variables; the concept of Prestige is denoted by PRES and measured by six observed variables; the concept of Attractiveness of the field is denoted by ATTR and measured by five observed variables; the concept of Media is denoted by MEDIA and measured by seven observed variables; the concept of University brand status is denoted by BRAND and measured by five observed variables; and the concept of Decision on University selection by Firstyear Business Administration students is denoted by DECISION and measured by four observed variables (see Table 1): 
Table 1: Measurements

\begin{tabular}{|c|c|}
\hline GL1 & The location of the University is easy to find. \\
\hline GL2 & The University is near my home. \\
\hline GL3 & I easily choose public transportation to the University. \\
\hline GL4 & The location of the University is convenient for renting a room at an affordable price. \\
\hline GL5 & The location of the University is convenient for part-time task. \\
\hline GL6 & The location of the University is convenient for taking extra classes. \\
\hline FAC1 & The University has spacious and clean facilities. \\
\hline FAC2 & The classrooms are equipped with a system of modern teaching equipment. \\
\hline FAC3 & The library is spacious, making readers comfortable. \\
\hline FAC4 & Lifts are arranged logically. \\
\hline FAC5 & Parking of the University meets enough space for students. \\
\hline FAC6 & Toilets are reasonably arranged and clean. \\
\hline FAC7 & The University campus is shaded by many green trees. \\
\hline PRES1 & The University has a good reputation among private universities. \\
\hline PRES 2 & I know that the University is very transparent about training issues. \\
\hline PRES 3 & I have heard many compliments about the University's teachers. \\
\hline PRES 4 & I know that many famous students who are alumni of the University. \\
\hline PRES5 & I know that the University is famous for its academic activities. \\
\hline PRES6 & I know that many outstanding students are currently students at the University. \\
\hline ATTR1 & Business Administration is one of the University's famous academic sectors. \\
\hline ATTR2 & While studying at the University, students have many opportunities to interact with businesses. \\
\hline ATTR3 & Students easily find a job in accordance with the major of Business Administration after graduation \\
\hline ATTR4 & Students are supported by the University to find jobs when they graduate. \\
\hline ATTR5 & Students of Business Administration receive financial support from the University. \\
\hline MEDIA1 & I knew a lot information about the University before deciding to enroll at the University. \\
\hline MEDIA2 & Easily find University's information on the media. \\
\hline MEDIA3 & The University's advisory staff works very well. \\
\hline MEDIA4 & The University has good advising enrollment at high universities. \\
\hline MEDIA5 & The University is organized for high university students to visit the University. \\
\hline MEDIA6 & The University's social networking site has provided a lot of useful information. \\
\hline MEDIA7 & The lecturers at the University are very good consultants. \\
\hline BRAND1 & The University is a trusted place for students studying Business Administration. \\
\hline BRAND 2 & I can easily distinguish the University brand from that of other Universities. \\
\hline BRAND 3 & I already knew the University brand. \\
\hline BRAND 4 & I can remember and recognize the logo and slogan of the University brand quickly. \\
\hline BRAND 5 & I am proud to be a Business Administration student at the University. \\
\hline DECISION1 & Compared to expectation, I am satisfied with my decision to choose this University. \\
\hline DECISION2 & Compared to the ideal university, I am pleased with the decision to choose this University. \\
\hline DECISION3 & I have faith in my decision to choose this University. \\
\hline DECISION4 & neral, choosing this University's Business Administration program is the right decision for me. \\
\hline
\end{tabular}




\subsection{Quantitative Research}

\subsubsection{Sampling}

Stratified sampling was used from Faculties of Business administration of five private universities in Ho Chi Minh city: HUTECH, Van Lang, Nguyen Tat Thanh, Hong Bang and Ho Chi Minh city University of Foreign languages Information Technology. Convenience sampling was also employed with a sample size of $500-100$ from each university. A total of 500 questionnaires were distributed, 450 ones collected, of which 424 were valid.

\subsubsection{Research Process}

The research process began with the elaboration of research objectives and the proposition of theoretical framework. The draft scale was then finalized by a focus group interview $(\mathrm{n}=30)$. The formal scale was finally arrived at and the quantitative research method was employed to quantify University brand factors affecting Firs-year Business Administration students' university selection. Primary data was processed using SPSS 20.0 software to measure the impact of University brand factors as follows: Cronbach's Alpha, Exploratory factor analysis, multiple linear regression, and PATH analysis.

\section{Results}

\subsection{Scale Reliability}

In Table 2, seven Cronbach's alphas, which range from 0,711 to 0,827 demonstrate high reliability measurement scales (GL6 variable was eliminated in the second analyzing to increase Cronbach's alpha to 0,798 ).

Table 2: Cronbach's Alpha of Brand Factor Scale

\begin{tabular}{|c|c|c|}
\hline Factor & Observed variables & $\begin{array}{c}\text { Cronbach's } \\
\text { Alpha }\end{array}$ \\
\hline Prestige & $\begin{array}{c}\text { PRES1, PRES2, PRES3, PRES4, } \\
\text { PRES5, PRES6 }\end{array}$ & 0,828 \\
\hline $\begin{array}{c}\text { Geographic } \\
\text { location }\end{array}$ & GL1, GL2, GL3, GL4, GL5 & 0,798 \\
\hline Facilities & $\begin{array}{c}\text { FAC1, FAC2, FAC3, FAC4, FAC5, } \\
\text { FAC6, FAC7, }\end{array}$ & 0,826 \\
\hline Attractiveness & ATTR1, ATTR2, ATTR 3, ATTR 4 & 0,800 \\
\hline Media & $\begin{array}{c}\text { MEDIA1, MEDIA2, MEDIA3, } \\
\text { MEDIA4, MEDIA5 }\end{array}$ & 0,797 \\
\hline $\begin{array}{c}\text { University } \\
\text { brand }\end{array}$ & $\begin{array}{c}\text { BRAND1, BRAND2, BRAND3, } \\
\text { BRAND4, BRAND5 }\end{array}$ & 0,776 \\
\hline $\begin{array}{c}\text { First-year students } \\
\text { decision }\end{array}$ & $\begin{array}{c}\text { DECISION1, DECISION2, } \\
\text { DECISION3, DECISION4, }\end{array}$ & 0,711 \\
\hline
\end{tabular}

\subsection{Exploratory Factor Analysis (EFA)}

In Table 3, 30 observed variables of five factors Prestige, Geographical location, Facilities, Attractiveness and Media - are analyzed by Principal components analysis and Varimax rotation. After eight rounds of analyzing, five factors are extracted from the 23 observed variables (ATTR5, FAC6, MEDIA1, FAC4, PRES6, PRES7, MEDIA6 variables were eliminated after seven analyses because of factor loading $<0,5$ ).

From the results of EFA in Table 3, the adjusted formal theoretical research model includes five factors influencing University brand. Specifically, this model has five component variables, including five independent variables (Geographical location, Facilities, Prestige, Attractiveness of the field, Media) and a dependent variable (University brand).

Table 3: Result of Exploratory Factor Analysis

\begin{tabular}{|c|c|c|c|c|c|}
\hline \multicolumn{5}{|c|}{ Rotated Component Matrix ${ }^{\mathbf{a}}$} \\
\cline { 2 - 6 } & $\mathbf{1}$ & $\mathbf{2}$ & $\mathbf{3}$ & $\mathbf{4}$ & $\mathbf{5}$ \\
\hline PRES2 & 0,733 & & 0,226 & & \\
\hline PRES4 & 0,728 & & & & 0,236 \\
\hline PRES5 & 0,726 & & & 0,249 & \\
\hline PRES3 & 0,672 & & & & \\
\hline PRES1 & 0,648 & & & & \\
\hline GL4 & & 0,726 & & & \\
\hline GL1 & & 0,718 & & & \\
\hline GL2 & & 0,695 & & & \\
\hline GL5 & & 0,677 & & & \\
\hline GL3 & & 0,675 & & & \\
\hline FAC1 & & & 0,738 & & \\
\hline FAC3 & & & 0,731 & & \\
\hline FAC2 & & & 0,676 & & \\
\hline FAC5 & & & 0,660 & & \\
\hline FAC7 & & & 0,591 & & \\
\hline ATTR3 & & & & 0,822 & \\
\hline ATTR2 & & & & 0,772 & \\
\hline ATTR4 & & & & 0,650 & \\
\hline ATTR1 & & & & 0,642 & \\
\hline MEDIA4 & & & & & \\
\hline MEDIA2 & & & & & \\
\hline MEDIA3 & & & & & \\
\hline MEDIA5 & & & & & \\
\hline \multicolumn{2}{|c|}{ Extraction Method: Principal Component Analysis } \\
\hline
\end{tabular}




\subsection{Regression Analysis}

$\mathrm{R}$ value is $0,786>0,5$. So, this model is appropriates for evaluating the relationship between dependent and independent variables. In addition, the R2 is 0,617 . This means the Multiple linear regression model is constructed in accordance with the $61,7 \%$ data. In other words, $61,7 \%$ University brand is explained by the Multiple linear regression model. The rest is due to errors and other factors. The Durbin Watson test result is 1,817 . It is in the range [1 $<\mathrm{D}<3$ ]. So, there is no correlation of the residuals (see Table 4).

In Table 4, the t-stat value of independent variables (Prestige, Geographical location, Facilities, Attractiveness of the field, Media) are higher than the value of $>$ t $\alpha / 2$ (1, n). Five t-stats, which range from 2,919 to 6,438 , are higher than $\mathrm{t} 0,025(5,418)=1,9656$ and five Sig. values are lower than 0,05 . In addition, the VIF coefficients of independent variables are lower than 2 , indicating no multicollinearity occurs.

Table 4: Statistical parameters of regression model

\begin{tabular}{|c|c|c|c|c|}
\hline \multirow{2}{*}{ Model } & $\begin{array}{c}\text { Standardized } \\
\text { coefficients }\end{array}$ & \multirow{2}{*}{$\mathbf{t}$} & \multirow{2}{*}{ Sig. } & $\begin{array}{c}\text { Collinearity } \\
\text { Statistics }\end{array}$ \\
\cline { 2 - 3 } \cline { 5 - 5 } & Beta & & & VIF \\
\hline (Constant) & & 1,639 & 0,102 & \\
\hline PRES & 0,153 & 4,172 & 0,000 & 1,474 \\
\hline GL & 0,260 & 6,390 & 0,000 & 1,811 \\
\hline FAC & 0,203 & 4,997 & 0,000 & 1,797 \\
\hline ATTR & 0,124 & 2,919 & 0,004 & 1,956 \\
\hline MEDIA & 0,257 & 6,438 & 0,000 & 1,745 \\
\hline \multicolumn{5}{|c|}{ Dependent variable: BRAND } \\
\hline
\end{tabular}

Note: VIF= Variance Inflation Factor

Based on Table 4, from the result of Standardized coefficients, the multiple linear regression equation of the factors affecting the University brand is as follows:

University brand $=\mathrm{a}_{0}+0,153 *$ Prestige $+0,260 *$ Geographic location $+0,203 *$ Facilities $+0,124 *$ Attractiveness of the field $+0,257 *$ Media

Thus, Prestige, Geographical location, Facilities, Attractiveness of the field, and Media factors all have a positive influence on the University brand. It means that the higher Prestige, Geographical location, Facilities, Attractiveness of the field and Media, the higher the University brand. Among these five factors, the most influential one is Geographical location, because its Standardized coefficient is highest $(\beta=0,260)$. Following are Media, Facilities, Prestige and Attractiveness. Thus, for the formal theoretical model of University brand, H1, H2, H3, H4, H5 hypotheses are accepted. The formal adjusted model of University brand, through the test results, is shown in Figure 1:

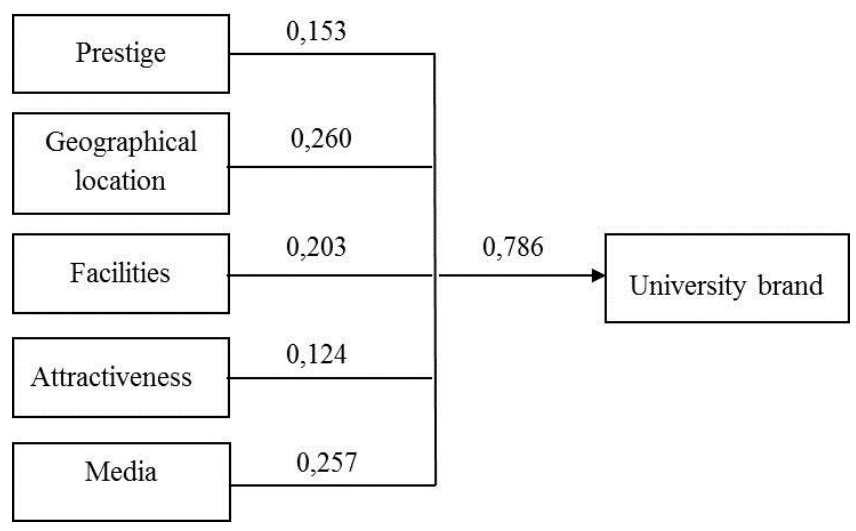

Figure 1: Adjusted model of University brand

\subsection{PATH Analysis}

The PATH model is used to analyze the influence of Prestige, Geographical location, Facilities, Attractiveness of the field and Media factors (independent variables) on the new student's decision (dependent variable) through University brand (intermediate variable). The analytical technique includes Linear regression in which University brand factor is the independent variable and First-year Business Administration students' Decision on University selection is the dependent variable (see Table 5).

In Table 5, $\mathrm{R}$ value is $0,817>0,5$. So, this model is appropriate to evaluate the relationship between dependent and independent variables. The t-stat value of independent variables (Confidence) $=29,137$ is higher than the value of $\mathrm{t}_{0,025}(1,422)=1,965$ and $\mathrm{Sig}$. values $=0,000$ is lower than 0,05 .

Table 5: Statistical parameters of PATH model

\begin{tabular}{|c|c|c|c|}
\hline \multirow{2}{*}{ Model } & $\begin{array}{c}\text { Standardized } \\
\text { coefficients }\end{array}$ & t & Sig. \\
\cline { 2 - 3 } & Beta & 6,020 & 0,000 \\
\hline (Constant) & 0,817 & 29,137 & 0,000 \\
\hline BRAND & Independent variable: BRAND \\
\hline \multicolumn{3}{|c|}{ Dependent variable: DECISION } \\
\hline
\end{tabular}

Based on Table 4, from the result of Standardized coefficient, the Simple linear regression equation of the 
factor affecting First-year Business Administration students' Decision on University selection is as follows:

First-year students' decision $=0,817$ * University brand

Brand factor has a strong positive influence on First-year students' decision. It means that the higher the University brand, the most likely is First-year Business Administration students' Decision to select the University.

$\mathrm{R}_{\mathrm{M}}^{2}$ fit coefficient of the PATH model:

$$
\mathrm{R}_{\mathrm{M}}^{2}=1-(1-0,6674) *(1-0,6177)=0,8724=87,24 \%
$$

$\mathrm{R}_{\mathrm{M}}^{2}$ fit coefficient of PATH model is very high.

Base on Table 4 and 5, the results of the formal PATH model is as follows (Figure 2):

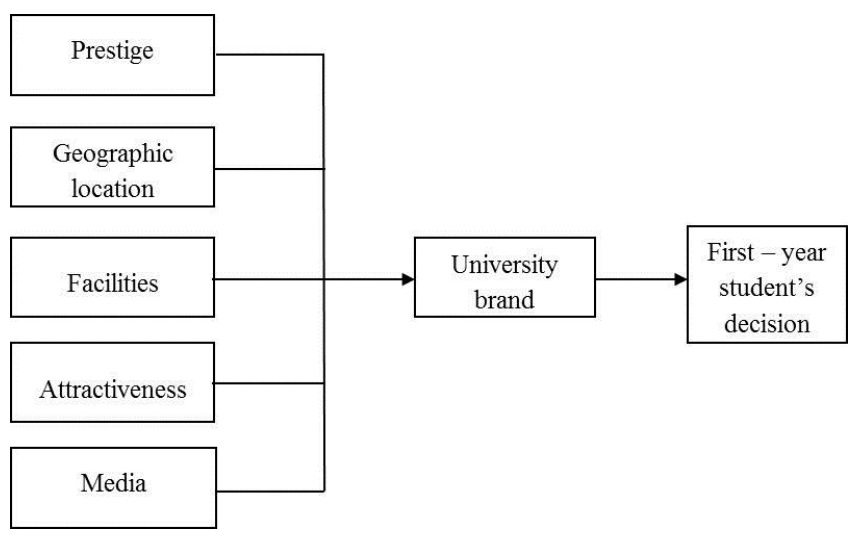

Figure 2: PATH model of First - year student's decision

\section{Discussion}

In the model proposed by the research team, a new factor is Geographical location, which has not been mentioned in models that have examined the University brand. The results show that the Geographical location factor composed of six variables (GL1, GL2, GL3, GL4, GL5, GL6) and GL6 variable was eliminated in the second round of analysis to increase Cronbach's alpha to 0,798 (Table 2). Five variables remained unchanged through EFA. Additionally, the competitive advantages of private universities are: (1) The location of the University is easy to find, (2) The University is near my home, (3) I easily choose public transportation to the University, (4) The location of the University is convenient for renting a room at an affordable price, and (5) The location of the University is convenient for part-time work. This factor has the most powerful effect (standardized $\beta=0,260$ ) on University brand. This justifies bringing the new factor Geographical location into enhancing University brand.
The Media factor has five observed variables (MEDIA1, MEDIA2, MEDIA3, MEDIA4, MEDIA5) with MEDIA1 variable being eliminated in analyzing EFA in the repeated study. However, Media is still the top consideration of new students when they choose a university to study for four years. This factor has the second strongest influence (standardized $\beta=0,257$ ) on University brand. This demonstrates that Media is still the top concern of the private universities in enhancing their brand to attract students.

The Facilities factor comprised seven observed variables (FAC1, FAC2, FAC3, FAC4, FAC5, FAC6, FAC7) by Cronbach's Alpha analysis, with FAC4, FAC6 being eliminated in EFA. Facilities factor is repeat study, however the result shows that this factor has little influence on University brand (standardized $\beta=0,203$ ), though nowadays, most private universities are boldly investing in the construction of new facilities and modern educational equipment.

The Prestige factor includes five observed variables (PRES1, PRES2, PRES3, PRES4, PRES5) by Cronbach's Alpha analysis and EFA. This factor is repeat study, as well. It has little influence on University brand (standardized $\beta=$ $0,153)$. Nowadays, most private universities have improved considerably their public image. In general, private universities develop their Business Administration programs to attract students. Therefore, it is no longer a matter of student interest.

The Attractiveness of the field factor is made up of five observed variables (ATTR1, ATTR2, ATTR3, ATTR4, ATTR5) by Cronbach's Alpha analysis, with ATTR5 being eliminated in EFA. The Attractiveness of the field factor is repeat study, however the result shows that this factor has the least influence to University brand (standardized $\beta=$ $0,124)$. This shows that most private universities create favorable conditions for students study at their Business Administration faculty, finding the right job after graduation. Therefore, it is no longer a matter of student interest as well.

The University brand of the field factor is a new component in the PATH model in the study of First-year students' decision process. The results show that the University brand factor consists of five observed variables (CON1, CON2, CON3, CON4, CON5, CON6) by Cronbach's Alpha analysis. This shows that students and their families still choose a university by its famous brand, because it makes commitments: The University is a trusted place for students studying Business Administration and the quality of the university's training services are reliable.

Through Cronbach's Alpha analysis, the First-year Business Administration students' Decision on University selection of factor retains four observed variables (DECISION1, DECISION2, DECISION3, DECISION4). 
This shows that a famous brand is the primary motivation for students and their families' selection of a university. A well-known university whose location is easy to find, and from where prestigious businesses recruit graduates is a dependable place for students to study.

The two-stage regression analysis shows:

Stage 1: Prestige, Geographical location, Facilities, Attractiveness of the field and Media factors (independent variables) have a proportional influence on the University brand factor (dependent variable). The most influential factor is Geographical location, followed by Media, Facilities, Prestige and Attractiveness of the field. With $\mathrm{R}=$ 0,786 and $\mathrm{R} 2=0,617$, this is an appropriate model to use to evaluate the relationship between dependent and independent variables.

Stage 2: The University brand factor (independent variable) has a strong influence on First-year students' decision factor (dependent variable), with $\mathrm{R}=0,817$ and $\mathrm{R} 2$ $=0,667$ (Table 4). The model explains $66,7 \%$ of the same effect direction on University brand with First-year students' decision. R2M fit coefficient of the PATH model is 0,8724 $(87,24 \%)$. These results are high, which show the interest of students and their families in choosing a famous university.

The results show that students, their families and society still have high confidence on a famous university brand. This proves that using PATH to test First-year Business Administration students' Decision on University selection in an enhancement model is appropriate. The more interest showed by the society, the better the value of University brand. The better the University brand, the more it attracts students.

\section{Managerial Implications and Conclusion}

Most of the student's life during university hours and part-time work is tied to university and local residence. Geographical location is the most influential factor in students' consideration of a university. A university that offers adequate facilities such as buildings, playgrounds, libraries, educational equipment, and natural surroundings, but also dormitory near the university, is very competitively placed to attract large numbers of students. Last, but not least, private universities should build dormitories and canteens to provide students with a comfortable environment and an inviting setup for learning (Le, 2019). Learning from the experience of the owner of a private university in Ho Chi Minh City, private universities should cooperate with well-known supermarkets such as Aeon, and Mini Stop, convenience stores to open branches on campus to provide students with high-quality breakfast, lunch and dinner at reasonable prices.
Nowadays, Ho Chi Minh City's real-estate prices are climbing sharply and inner city traffic congestion is getting worse. Therefore, private universities should move to suburban areas. The main campus and operational centers should be integrated at the same place to facilitate the management, teaching and learning. In the future, metro lines should be built to help students come to university easily. However, metro stations have few highway crossings and bus stops. Private universities should build facilities next to metro stations to give students' easy access to university (Le, 2019). Learning from the experience of the owners of two universities in Ho Chi Minh City, they acquire unfinished buildings there a company that went bankrupt. It is a cheap and affordable way to buy properties, and they do not require a construction permit. It only needs redesigning and furbishing to suit teaching activities. Thus, the investor will own a spacious, modern university in the center of the city.

In the future, the Ministry of Education and Training will raise entry requirements of enrolling universities. Thus, competition for new students among universities in general and private universities in particular will be more pronounced. Therefore, when it comes to student attraction, a university with a well-respected brand has an enormous advantage. A solution for attracting students to learn Business Administration and enhance the level of competition with public universities should be for AUN to accredit Business Administration programs of private universities in Vietnam. University programs that receive the quality verification certificate from AUN is a testament to the quality of education that students and their families will appreciate.

Today, in the fierce competition among private universities in Ho Chi Minh City, in particular, and in the country, in general, media is the most important consideration affecting First-year students' Decision on University selection. A university that handle Media very efectively will attract a large number of students. So, Media is currently the most important aspect universities should pay attention to. Each university should set up a Consultancy-Enrollment-Media department in order to promote the university image to the public, and counseling students and their families about the university's Business Administration curriculum. Enrollment in many universities usually begins in the summer to get students ready for the start of the university year. To attract students into Business Administration programs, the media should play a key role in students enrollment at top private universities across the country starting at the beginning of the academic year and ending at Summer's end. It takes a long time to communicate the university image to students, and be effective in attracting students. In order to improve the effectiveness of Consultancy - Enrollment - Media, 
universities need to be more active in promotional activities in newspapers, television, and sponsors, and organize admissions counseling on television as well as directly in top universities.

In fact, Business Administration programs across universities are similar in terms of subjects, training methods, number of years of study, etc. Therefore, to attract students, universities must create a distinctive edge such as business relations activities, student support schemes for job search, strengths of the university in training, extracurricular activities related to entrepreneurship and business internship, exemplary achievements of alumni, etc.

Firms gain employees without having to hire them directly, as the burden of hiring capable students rests on the university faculty. Industry thus gains well-trained workers without having to go through the search and interview process. The students who work on these projects are also monitored by company personnel, providing insight into their capabilities as potential full-time employees. So, private universities should link with wellknown businesses in order to further attract students. Through the learning process, students will not only gained practical access to businesses, but also be recruited after graduation.

To build the Prestige of university is a long-term process, synthesizing all aspects and all factors affecting the effectiveness of the teaching and training of new age students. Promotion and communication must be done in such a way for society to recognize and value prestige among private universities, so that parents and students hear compliments about university teachers as well as success stories from famous university alumni. How to get students to develop the brand of the university?. Each student is a university ambassador. There should be group activities where all members wear the university's branded shirt. This will greatly impact the decision of new students in their choice of university.

\section{References}

Balmer, J. M. T. (2001). Corporate identity, corporate branding and corporate marketing - Seeing through the fog. European Journal of Marketing, 35(3/4), 248-291.

Bennett, P. D. (1995). Dictionary of Marketing Terms (2 ${ }^{\text {nd }}$ ed.). Chicago, IL: American Marketing Association.

Bulotaite, N. (2003). University heritage - an institutional tool for branding and marketing. Higher Education in Europe, 28(4), 449-454.

Burn, M. J. (2006). Factors influencing the college choice of African-American students admitted to the college of argiculture, food and natural resources ( $\mathrm{PhD}$ Thesis). University of Missouri-Columbia, Columbia, Missouri.

Cabera, A. F., \& La Nasa, S. M. (2000). Understanding the college choice of disadvantage students. New Direction for Institution
Research. San Francisco, CA: Jossey-Bass.

Chapleo, C. (2010). What defines "successful" university brands? International Journal of Public Sector Management, 23(2), 169-183.

Chapleo, C. (2011). Exploring rationales for branding a university: Should we be seeking to measure branding in UK universities? Journal of Brand Management, 18(6), 411-422.

Chapman, D. W. (1981). A model of student university choice, The Journal of Higher Education, 52(5), 490-505.

Davis, S. (2002). Implementing your BAM2 strategy: 11 steps to making your brand a more valuable business asset. Journal of Consumer Marketing, 19(6), 503-513.

Hacker, H. M. (2005). Thinking about education. The Dallas Morning News. Retrieved November 10, 2019, from https://www.dallasnews.com/news/education/.

Harvey, J. A. (1996). Marketing universities and consumer choice. International Journal of Educational Management, 10(4), 2632.

Hemsley-Brown, J., \& Goonawardana, S. (2007). Brand harmonization in the international higher education market. Journal of Business Research, 60(9), 942-948.

Howard, J. A., \& Sheth, J.N. (1969). The Theory of Buyer Behavior. London, UK: John Wiley and Sons, Inc.

Kotler, P., \& Bliemel, F. (1999). Marketing - Management: Analyse, Planung, Umsetzung und Steuerung. Stuttgart, Germany: Schäffer-Poeschel.

Le, Q. H., Nguyen, P. T., Tran, T. T., Diep, T. P. T., Ngo, N. C., Tran, T. C, H., \& Nguyen, T. H. Y. (2014). Synthesized group of factors influencing the choice decision of students' Business Administration Faculty - HUTECH. Scientific Research Projects, Ho Chi Minh City University of Technology (HUTECH), Vietnam.

Le, Q. H. (2017). HUTECH's Brand value through the feeling of students. Finance Journal, 9/2017, 69-72.

Le, Q. H. (2019). Factors affecting brand values of private universities: A case study of HUTECH. Journal of Asia Finance, Economics and Business, 6(1), 159-167. http://doi.org/10.13106/jafeb.2019.vol6.no1.159.

McNally, D., \& Speak, K. D. (2002). Be your own brand. American Salesman, 47(7), 29-30.

Murphy, J. M. (1987). Branding: A key marketing tool. London, UK: Macmillan.

Ngo, Q. H., Nguyen, Q. T., Nguyen, T. L., Tran, V. T., \& Hoang, M. T. (2019). Factors Affecting Brand and Student Decision Buying Fresh Milk: A Case Study in Ho Chi Minh City, Vietnam. Journal of Asia Finance, Economics and Business, 6(3), 247-258.

http://doi.org/10.13106/jafeb.2019.vol6.no3.247.

Nguyen, D. T., \& Nguyen, T. M. T. (2011). Scientific Research Marketing. Ho Chi Minh City, Vietnam: Labor - Social Publishing.

Nguyen, Q. T., \& Nguyen, T. T. H. (2020). Factors Affecting Industry and University Collaboration in Education in the Hospitality Industry in Vietnam: A Business Perspective. Journal of Asia Finance, Economics and Business, 7(2), 291300. http://doi.org/10.13106/jafeb.2020.vol7.no2.291.

Nguyen, T. S., \& Nguyen, T. M. (2014). Advertising factors affecting the image and reputation of Foreign Trade University. Scientific Journal of Ho Chi Minh City Open 
University, 44(5), 28-37.

Nguyen, T. T. (2015). Employee - Based brand equity in higher education: a study in Vietnam ( $\mathrm{PhD}$ Thesis). Ho Chi Minh City University of Economics, Ho Chi Minh City, Vietnam.

Schackner, B. (2004). Point Park University in Pittsburg launches 'branding' campaign. Pittsburg Post-Gazette. Retrieved
November 27, 2019, from http://www.highbeam.com.

Sultan, P., \& Ho, Y. W. (2014). An integrated-process model of service quality, institutional brand and behavioural intentions: The case of a University. Managing Service Quality, 24(5), 487-521. 